This item is the archived peer-reviewed author-version of:

\title{
Flow cytometric analysis of drug-induced basophil histamine release
}

\section{Reference:}

Cop Nathalie, Uyttebroek Astrid, Sabato Vito, Bridts Christiaan, De Clerck Luc S., Ebo Didier.- Flow cytometric analysis of druginduced basophil histamine release

Cytometry: part B: clinical cytometry - ISSN 1552-4949 - (2015), p. 1-10

Full text (Publishers DOI): http://dx.doi.org/doi:10.1002/cyto.b.21226

To cite this reference: http://hdl.handle.net/10067/1236180151162165141 


\section{Flow cytometric analysis of drug-induced basophil histamine release}

Cop $\mathrm{N}, \mathrm{MS}^{1}$, Uyttebroek $\mathrm{AP}, \mathrm{MD}^{1}$, Sabato $\mathrm{V}, \mathrm{MD}^{1}$, Bridts $\mathrm{CH}, \mathrm{MT}^{1}$, De Clerck $\mathrm{LS}, \mathrm{MD}, \mathrm{PhD}^{1}$, Ebo $\mathrm{DG}, \mathrm{MD}$, $\mathrm{PhD}^{1, *}$

${ }^{1}$ Faculty of Medicine and Health Science

Department of Immunology - Allergology - Rheumatology University of Antwerp, Antwerp University Hospital, 2610 Antwerpen, Belgium

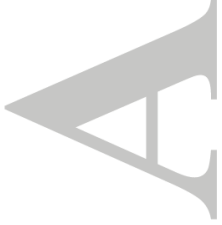

*Correspondence to:

D. G. Ebo,

Department of Immunology, Allergology, Rheumatology,

University of Antwerp,

Faculty of Medicine and Health Science,

Campus Drie Eiken T5.95,

Universiteitsplein 1,

2610 Antwerpen, Belgium.

Email: immuno@uantwerpen.be

Key words: basophil activation, flow cytometry, IgE, rocuronium

This article has been accepted for publication and undergone full peer review but has not been through the copyediting, typesetting, pagination and proofreading process which may lead to differences between this version and the Version of Record. Please cite this article as an 'Accepted Article', doi: 10.1002/cyto.b.21226 


\section{Abstract}

Histamine and its release can be studied by multicolor flow cytometry on a single cell level by an enzyme affinity method (HistaFlow ${ }^{\circledR}$ ). However, for the time-being, the clinical and scientific application of the HistaFlow $^{\circledast}$ technique remains limited. This study aims at verifying the reliability of the HistaFlow ${ }^{\circledR}$ as an instrument to quantify IgE-mediated basophil responses to drugs, i.e. rocuronium, which are believed to be less potent basophil activators than large proteinaceous allergens.

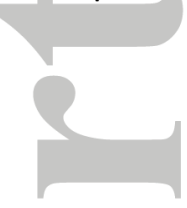

Ten patients and three exposed control individuals were included in this study. Each subject underwent in vitro basophil activation tests $\left(\right.$ HistaFlow $\left.^{\circledR}\right)$ with 0.16 and $1.6 \mathrm{mmol} / \mathrm{L}$ rocuronium.

Patients showed an activation of basophils ranging from 11 to $86 \%$ of CD63 positive basophils and a median histamine release per cell from 68 to $100 \%$ after stimulation with an optimal concentration of $1.6 \mathrm{mmol} / \mathrm{L}$ rocuronium. For the control individuals no activation was demonstrable.

This study confirms that the HistaFlow ${ }^{\circledR}$ technique is a reliable tool to study histamine release by individual cells in response to drugs. Although the HistaFlow ${ }^{\circledR}$ technique will probably not add to the diagnostic management of rocuronium allergy, our findings suggest that the technique could constitute an important asset for future studies on the pathomechanism(s) of immediate drug hypersensitivity reactions.

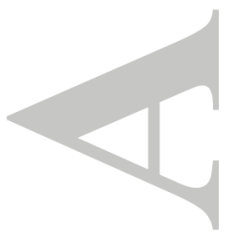

John Wiley and Sons, Inc. 


\section{Introduction}

Upon encountering allergens that cross-link FceRI-bound specific IgE (slgE), basophils release different mediators, such as histamine and leukotrienes. Traditionally, release of these mediators is quantified using assays measuring their extracellular content in the supernatant of all degranulated cells $(1,2)$. Recently, we provided the proof-of-concept that histamine and its release can also be studied by multicolor flow cytometry on a single cell level by an enzyme affinity method (HistaFlow ${ }^{\circledR}$ ) based on the affinity of the histaminase diamine oxidase (DAO) for its substrate histamine (3). However, for the timebeing, the clinical and scientific application of the HistaFlow ${ }^{\circledR}$ technique remains limited.

This study aims at verifying the reliability of the HistaFlow ${ }^{\circledast}$ as an instrument to quantify IgE-mediated basophil responses to drugs, which are believed to be less potent basophil activators than large proteinaceous allergens. Rocuronium allergy, a rare but life threatening condition, was chosen as a model, mainly because IgE-mediated allergy to this neuromuscular blocking agent (NMBA) can robustly be established using a combination of skin testing, quantification of slgE and traditional basophil activation tests (4).

\section{Materials and methods}

Patients and control individuals

Ten patients ( 5 female, median age 59 years (31-62) and 5 male, median age 51 years (38-63)) were selected and evaluated as detailed elsewhere (5). Briefly, patients had presented hypotension and/or bronchospasm within $5 \mathrm{~min}$ after injection of rocuronium and clinical suspicion of rocuronium hypersensitivity was documented by a positive skin test (ST) and basophil activation test (BAT). Three uneventfully rocuronium-exposed control individuals ( 1 female, age 57 years and 2 male, median age 39 years (12-66)) with a negative ST were also included. Participants gave a written informed consent as approved by the Ethical Committee of the University Hospital Antwerp (Belgium B300201316408). 


\section{In Vitro Activation of Basophils}

Analysis of in vitro basophil activation was performed as described by Ebo et al. (3). Briefly, $200 \mu \mathrm{L}$ endotoxin-free heparinized whole blood were challenged at $37^{\circ} \mathrm{C}$ for 20 min with $200 \mu \mathrm{L}$ buffer as a negative control, $200 \mu \mathrm{L}$ anti-lgE (Pharmingen, BD Bioscience, Erembodegem, Belgium) as a positive control, and $200 \mu \mathrm{L}$ of an end concentration of $0.16 \mathrm{mmol} / \mathrm{L}$ and $1.6 \mathrm{mmol} / \mathrm{L}$ rocuronium. Stimulation with an end concentration of $1.6 \mathrm{mmol} / \mathrm{L}$ has been proven to be the optimal concentration in previous research (5). Reactions were stopped by chilling on ice, adding $1 \mathrm{~mL}$ ice-cooled PBS with $10 \mathrm{mmol} / \mathrm{L}$ EDTA and spinning for $5 \mathrm{~min}\left(4^{\circ} \mathrm{C}, 200 \mathrm{~g}\right)$. To select and quantify basophil activation, cells were stained with $20 \mu \mathrm{L}$ of monoclonal anti-human IgE (clone GE-1, Sigma Aldrich GmbH, Steinheim, Germany) labeled with Alexa Fluor 405 (Molecular Probes, Invitrogen, Paisley, UK), $10 \mu \mathrm{L}$ of monoclonal antihuman CD63-FITC (clone H5C6, BD Biosciences, Erembodegem, Belgium) and $10 \mu \mathrm{L}$ CD203c-APC (clone NP4D6, Biolegend, San Diego, CA, USA) for $20 \mathrm{~min}$ on ice. Cells were lysed/fixed with $2 \mathrm{~mL}$ Phosflow Lyse/Fix buffer (BD Biosciences, Erembodegem, Belgium) for $20 \mathrm{~min}\left(37^{\circ} \mathrm{C}\right)$. Cells were washed with and resuspended in PBS with $0.1 \%$ Triton-X-100 (PBS-TX, pH=7.4). To stain intracellular histamine $10 \mu \mathrm{L}$ PElabeled DAO (BD Biosciences, Erembodegem, Belgium) was added and incubated at $37^{\circ} \mathrm{C}(45 \mathrm{~min})$. Cells were washed and re-suspended in PBS with $0.1 \%$ sodium azide and measured.

Flow Cytometric Analysis

Flow cytometric analysis was performed on a FACSCanto II flow cytometer (BD Immunocytometry Systems, San Jose, CA) equipped with three lasers (violet - $405 \mathrm{~nm}$, blue $-488 \mathrm{~nm}$ and red $-635 \mathrm{~nm}$ ) to detect 8 colors including fluorochromes used as described by Ebo et al. (3). Correct compensation settings for these fluorochromes were performed using BD CompBeads (BD Biosciences, Erembodegem, Belgium). Fluorescence minus one (FMO) and DAO staining with and without permeabilization was used to set a marker between DAO positive and negative cells. Flow cytometric characterization of basophils relied upon a combination of side scatter (SCC), anti-IgE and CD203c. Standardization of intracellular 
histamine content was performed using standardized fluorospheres (SPHERO Ultra Rainbow Calibration particles, Spherotech, Lake Forest, IL) as described by the manufacturer. Results were expressed as \% CD63 positive basophils and as the \% median histamine release per basophil (\%MHC). MHC percentage was calculated as the ratio of the difference between MFI/cell in non-degranulating $\left(\mathrm{CD} 203 \mathrm{c}^{\operatorname{dim}}\right.$ and $\left.\mathrm{CD}^{-}\right)$basophils minus the $\mathrm{MFI} /$ cell in degranulating $\left(\mathrm{CD} 203 \mathrm{c}^{\mathrm{hi+}}\right.$ and $\left.\mathrm{CD}^{-} 3^{+}\right)$basophils, against the $\mathrm{MFI}$ per cell in non-degranulating $\left(\mathrm{CD}^{203 c^{\operatorname{dim}}}\right.$ and $\left.\mathrm{CD}^{\circ}\right)$ basophils multiplied by $100(\% \mathrm{MHC}=$

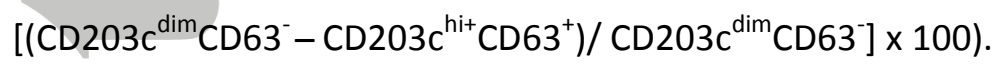

\section{Statistical analysis}

Results were expressed as median and range. The Mann-Whitney U-test was used to state significant differences between the controls and patients. Differences were considered significant at a $P$ value less than 0.05 .

\section{Results}

When stimulated with rocuronium $1.6 \mathrm{mmol} / \mathrm{L}$, basophils of the patients showed an up-regulation of CD63 ranging from 11 to $86 \%$ (Fig 1.A.) and median histamine release per cell (MHC) varying between 68 to $100 \%$ MHC (Fig. 1B). In contrast, in rocuronium-exposed control individuals, no rocuroniuminduced CD63 up-regulation nor histamine release was demonstrable (Fig. 1). Figure 2 shows a representative HistaFlow ${ }^{\circledR}$ plot of a patient with an allergy to rocuronium (Fig. 2).

\section{Discussion}

Although for many the reference assay for effector cell activation remains the basophilic histamine release tests (6), these techniques have never entered mainstream diagnostic application and have now been largely supplanted by the basophil activation test (BAT). Traditional BAT relies upon flow cytometric quantification of alterations of specific activation or degranulation markers on the surface membrane of the cell (7). Moreover, it has been demonstrated that flow cytometry enables to combine analysis of surface markers with a simultaneous 
study of intracellular signaling molecules such as p38 MAPK (mitogen-activated protein kinase) (8) and STAT 5 (signal transducer and activator of transcription) (9) and, most interestingly, quantification of intracellular histamine and its release by in vitro activated basophils (3). However, for the time being, the technique of flow cytometric quantification of intracellular histamine content and histamine release, which is called HistaFlow ${ }^{\circledR}$, is still in its infancy and literature is restricted to a proof-of-concept in birch pollen allergy (3) and a follow-up study in wasp venom immunotherapy (10). With respect to drugs, which are generally considered less potent basophil activators than larger proteinaceous allergens, the technique has only been applied in 3 cases who suffered from an immediate reaction to the opiate antitussive pholcodine (11) and one patient with a cephazolin allergy (12).

The current study confirms that the HistaFlow ${ }^{\circledR}$ technique also enables to demonstrate histamine release by small chemicals that generally elicit relative little basophil activation such as drugs. Since this semi-quantitative study does not aim at calculating the real intracellular histamine content, but rather at describing the mechanism of immediate drug hypersensitivity, the chosen wide spectrum calibration method seems sufficient. Although the HistaFlow $^{\circledR}$ technique will probably not add to the diagnostic management of rocuronium allergy, our findings suggest that the technique could constitute an important research asset for future studies about immediate drug hypersensitivity reactions (IDHR) (13). First, HistaFlow ${ }^{\circledR}$ experiments closely mirror the in vivo pathway leading to symptoms of IDHR. Second, the technique captures data that are inaccessible for traditional mediator release assays requiring homogeneous cell populations and of which results merely represent an average of isolated cells analyzed. Third, as already exemplified, $\mathrm{HistaFlow}^{\circledR}$ allows an integrated analysis of mediator release, intracellular signaling and alterations of surface activation markers and inhibitory receptors such as CD300a (inhibitory receptor of $60 \mathrm{kDa})$. In fact, it is anticipated that by extending the experiments to intracellular signaling $(8,14)$ and inhibitory receptors (15) the HistaFlow ${ }^{\circledR}$ technique might unveil novel insights into drug-specific basophil degranulation patterns. One particularly interesting area we believe to be perfectly manageable for experimental examination by the HistaFlow ${ }^{\circledR}$ technique relates to the pathomechanism(s) of IDHR. Because effector cell degranulation does not per se require IgE/FceRI cross-linking, the technique might also be valuable to study IgEindependent IDHR resulting from alternative means of cell activation (e.g. anaphylatoxins such as C5a and C3a, pathogen-associated molecular patterns (PAMPs) or direct mast cell activation). For example, the technique could 
contribute to resolve the recent controversy about the basophil activation potential of quinolones such as moxifloxacin (16).

In conclusion, this study confirms flow cytometry to constitute a reliable tool to study histamine release by individual cells in response to drugs in both an IgE-dependent and IgE-independent basophil activation and subsequent degranulation. Furthermore, it is anticipated that the technique might disclose fundamental insights into distinct drug-induced basophil degranulation patterns.

\section{Acknowledgments}

The authors thank Mrs. Christel Mertens for her technical skills. This study was partly funded by a research fund of the University of Antwerp (GOA no. 6247). Vito Sabato is a clinical researcher of the Research Foundation Flanders (FWO: 1700614N). Didier Ebo is a senior clinical researcher of the Research Foundation Flanders (FWO: $1800614 N)$.

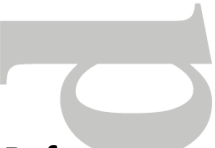

\section{References}

1. Frandsen PM, Krohn IJ, Hoffmann HJ, Schiotz PO. The Influence of IgE on Cultured Human Mast Cells. Allergy Asthma Immunol Res 2013;5:409-14.

2. MacGlashan DW, Jr. Basophil activation testing. J Allergy Clin Immunol 2013;132:777-87.

3. Ebo DG, Bridts CH, Mertens CH, Hagendorens MM, Stevens WJ, De Clerck LS. Analyzing histamine release by flow cytometry (HistaFlow): a novel instrument to study the degranulation patterns of basophils. J Immunol Methods 2012;375:30-8.

4. Leysen J, Bridts CH, De Clerck LS, Vercauteren M, Lambert J, Weyler JJ, Stevens WJ, Ebo DG. Allergy to rocuronium: from clinical suspicion to correct diagnosis. Allergy 2011;66:1014-9.

5. Ebo DG, Bridts CH, Hagendorens MM, Mertens CH, De Clerck LS, Stevens WJ. Flow-assisted diagnostic management of anaphylaxis from rocuronium bromide. Allergy 2006;61:935-9.

6. Demoly P, Lebel B, Arnoux B. Allergen-induced mediator release tests. Allergy 2003;58:5.

7. Ebo DG, Bridts CH, Hagendorens MM, Aerts NE, De Clerck LS, Stevens WJ. Basophil activation test by flow cytometry: present and future applications in allergology. Cytometry B Clin Cytom 2008;74:201-10.

8. Ebo DG, Dombrecht EJ, Bridts CH, Aerts NE, de Clerck LS, Stevens WJ. Combined analysis of intracellular signalling and immunophenotype of human peripheral blood basophils by flow cytometry: a proof of concept. Clin Exp Allergy 2007;37:1668-75.

9. Verweij MM, Sabato V, Nullens S, Bridts CH, De Clerck LS, Stevens WJ, Ebo DG. STAT5 in human basophils: IL-3 is required for its FcepsilonRI-mediated phosphorylation. Cytometry B Clin Cytom 2012;82:101-6.

10. Nullens S, Sabato V, Faber M, Leysen J, Bridts CH, De Clerck LS, Falcone FH, Maurer M, Ebo DG. Basophilic histamine content and release during venom immunotherapy: insights by flow cytometry. Cytometry B Clin Cytom 2013;84:173-8.

11. Leyseh J, De Witte L, Sabato V, Faber M, Hagendorens M, Bridts C, De Clerck L, Ebo D. IgE-mediated allergy to pholcodine and cross-reactivity to neuromuscular blocking agents: Lessons from flow cytometry. Cytometry B Clin Cytom 2013;84:65-70. 
12. Baldo BA, Pham NH. Drug Allergy: Clinical Aspects, Diagnosis, Mechanisms, Structure-Activity Relationships: Springer; 2013. 447 p.

13. Uyttebroek AP, Sabato V, Faber M, Cop N, Bridts CH, Lapeere H, De Clerck LS, Ebo DG. Basophil activation tests: time for a reconsideration. Expert Rev Clin Immunol 2014.

14. Verweij MM, De Knop KJ, Bridts CH, De Clerck LS, Stevens WJ, Ebo DG. P38 mitogen-activated protein kinase signal transduction in the diagnosis and follow up of immunotherapy of wasp venom allergy. Cytometry B Clin Cytom 2010;78:302-7.

15. Sabato V, Verweij MM, Bridts CH, Levi-Schaffer F, Gibbs BF, De Clerck LS, Schiavino D, Ebo DG. CD300a is expressed on human basophils and seems to inhibit IgE/FcepsilonRI-dependent anaphylactic degranulation. Cytometry B Clin Cytom 2012;82:132-8.

16. Uyttebroek AP, Sabato V, Bridts CH, Ebo DG. In vitro diagnosis of immediate IgE-mediated drug hypersensitivity: warnings and (unmet) needs. Immunol Allergy Clin North Am 2014;34:681-9.

\section{Figure 1. Basophil activation test and median histamine release per cell expressed as \% MHC results after} stimulation with $1.6 \mathrm{mmol} / \mathrm{L}$ rocuronium.

(A) Basophil activation test. Circles: Rocuronium-induced CD63 expression in control individuals with a negative ST after exposure to rocuronium. Squares: Patients allergic to rocuronium confirmed by a positive ST and BAT. The line represents the median.

(B) \%MHC: Circles: Rocuronium-induced \% median histamine release per cell (MHC) in control individuals with a negative ST after exposure to rocuronium. Squares: Responsive patients allergic to rocuronium confirmed by a positive ST and BAT. The line represents the median.

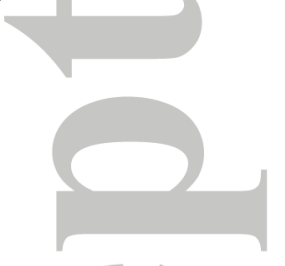

Figure 2. Representative sample of histamine release after IgE/FceRI cross-linking and activation by rocuronium.

(A) Selection of unique cells based on forward scatter (FCS) area and height plot. (B) Basophils are gated out as IgE high positive cells and (C) $\mathrm{CD} 203 \mathrm{c}^{+}$cells. (D) Activation with anti-IgE as a positive control led to an up regulation of CD203c. (E) Histamine (DAO) and CD63 expression upon stimulation with buffer as a negative control. (F) Activation of basophils with anti-IgE resulted in histamine release by $73 \%$ of basophils (DAO- cells). (G) Upon stimulation with $0.16 \mathrm{mmol} / \mathrm{L}$ rocuronium no histamine release was noticeable in this sample. $(\mathbf{H})$ Stimulation with $1.6 \mathrm{mmol} / \mathrm{L}$ rocuronium led to a $52 \%$ release of the basophils' histamine content. 

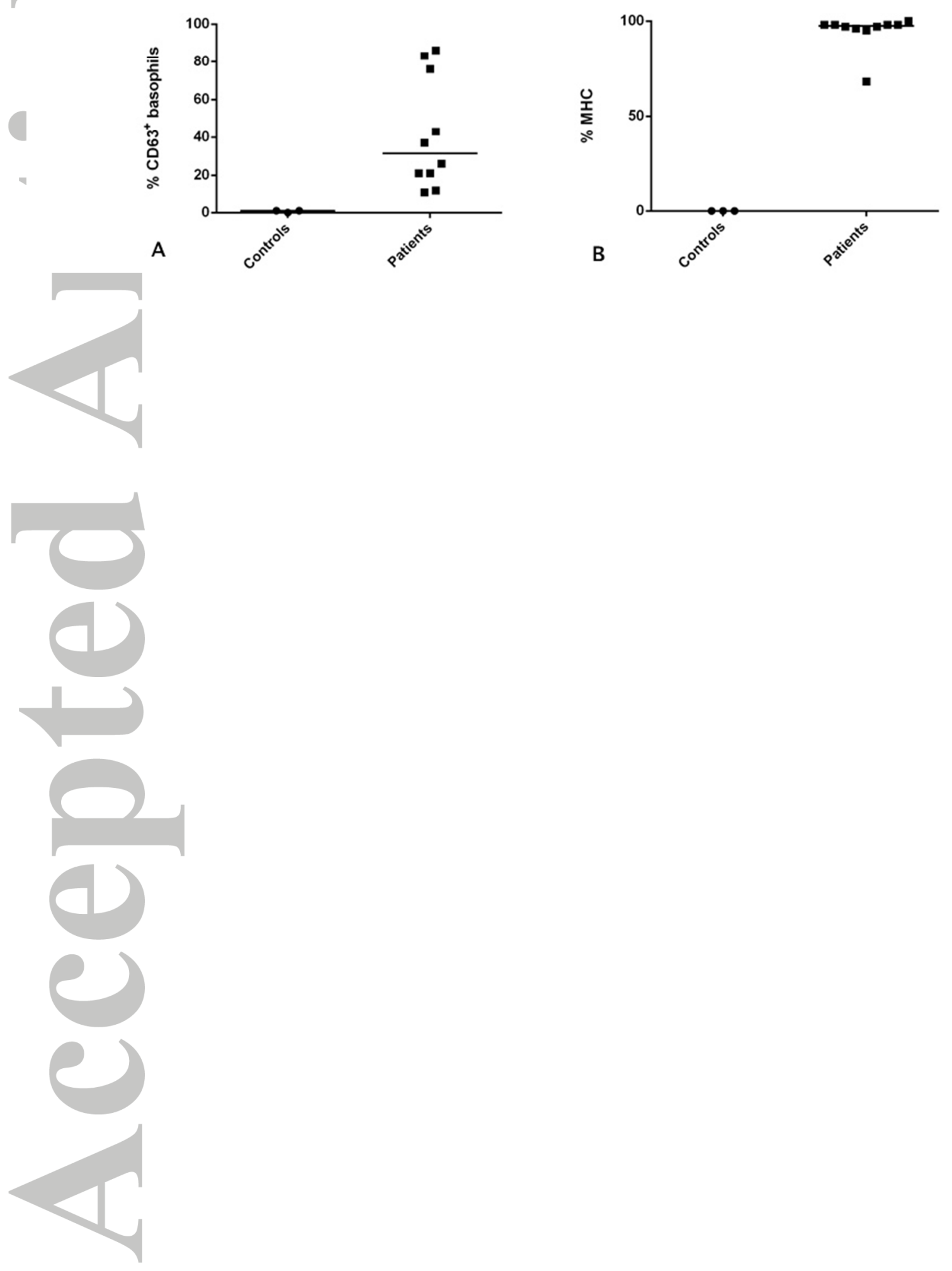

John Wiley and Sons, Inc.

This article is protected by copyright. All rights reserved. 

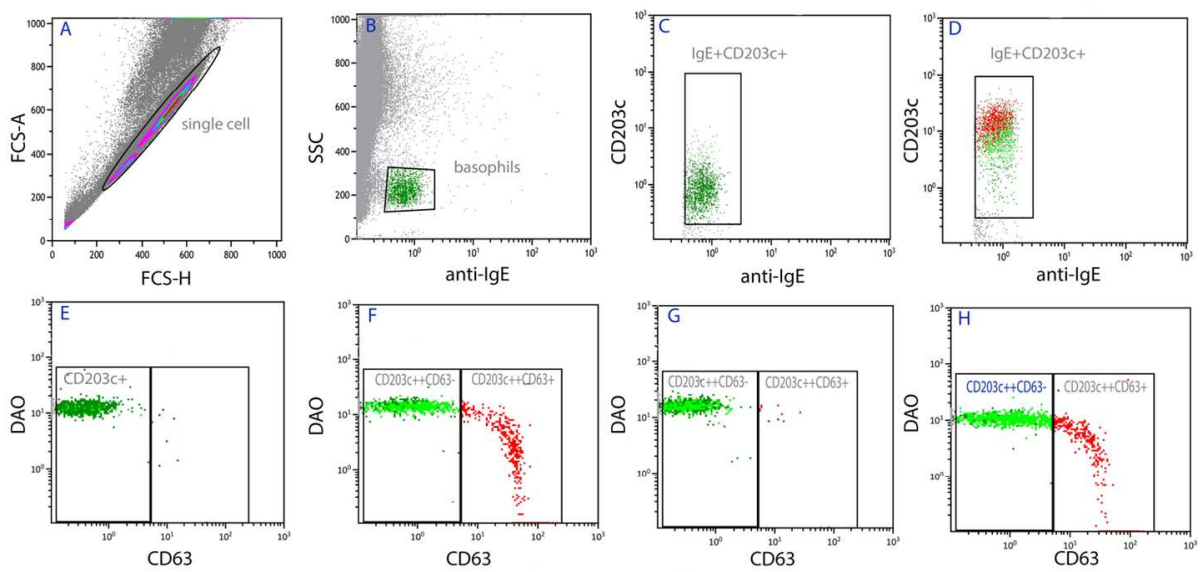

$135 \times 66 \mathrm{~mm}(300 \times 300$ DPI $)$

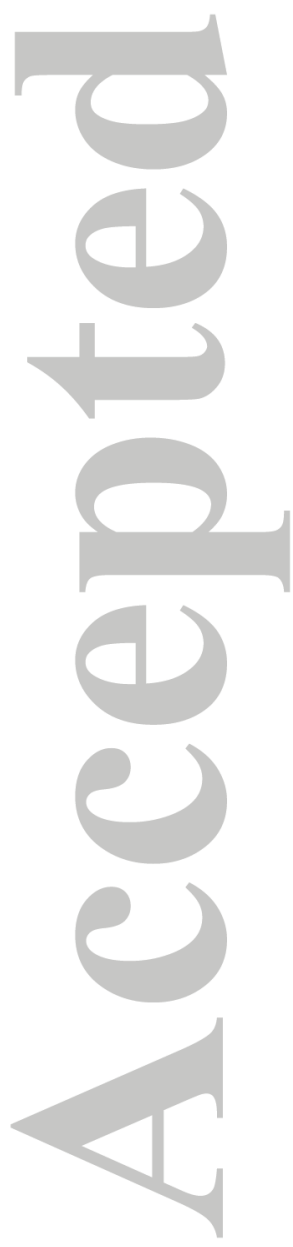

John Wiley and Sons, Inc.

This article is protected by copyright. All rights reserved. 